\title{
INFLATION'S CHILDREN: TALES OF CRISES THAT BEGET REFORMS
}

\author{
Michael Bruno \\ William Easterly
}

Working Paper 5452

\section{NATIONAL BUREAU OF ECONOMIC RESEARCH 1050 Massachusetts Avenue \\ Cambridge, MA 02138 \\ February 1996}

This paper is part of NBER's research programs in International Finance and Macroeconomics and Monetary Economics. Any opinions expressed are those of the authors and not those of the National Bureau of Economic Research.

(c) 1996 by Michael Bruno and William Easterly. All rights reserved. Short sections of text, not to exceed two paragraphs, may be quoted without explicit permission provided that full credit, including (C) notice, is given to the source. 


\title{
INFLATION'S CHILDREN: TALES OF CRISES THAT BEGET REFORMS
}

\begin{abstract}
Are broad reforms the children of high inflation? Do growth recoveries follow? We find that countries that had external debt crises with high inflation both reformed more and recovered better than countries that had external debt crises with low inflation. Countries with extremely high inflation also later wound up with lower inflation than countries that has moderately high inflation. The low inflation debtor countries had more aid than the high inflation debtor countries, which may have created stronger incentives to reform in the high inflation countries. Recent reforms look like they are the children of high inflation, even if further paternity tests are in order.
\end{abstract}

Michael Bruno

Room N-6-043

The World Bank 1818 H Street NW

Washington, DC 20433

and NBER
William Easterly

Room N-11-069

The World Bank

1818 H Street NW

Washington, DC 20433 


\section{Inflation's Children: Tales of Crises that Beget Reforms Michael Bruno and William Easterly*}

Are broad reforms the children of high inflation? Do growth recoveries follow? Bruno and Easterly 1995 looked at countries that had discrete high inflation crises -- inflation above 40 percent annual for two or more years. We found that growth falls sharply during the high inflation crisis. However, growth after the end of the high-inflation crisis was higher than before the crisis - even though inflation had returned to about the pre-crisis level or slightly higher. Easterly 1995 in a follow-up paper found that GDP growth was positive already in the first year that high inflation declined from its pre-stabilization peak. Growth keeps getting more and more positive as the stabilization continues, up to about 3 percent per capita growth after seven years. We were surprised at the speed and magnitude of the growth recovery following stabilization of high inflation. Here we begin to explore three questions raised by our previous finding: (1) was the growth recovery after the end of high inflation simply a mechanical one that happens after any macroeconomic crisis? (2) did high inflation crises make countries act on both stabilization and reform? (3) what was the role of aid in crisis and reform?

I. Does growth mechanically recover after crises?

Most of the high inflation countries had external debt crises. We can compare crisis debtors with inflation crisis-and-stabilization to those that had persistent low inflation to see if mechanical recovery occurs in both groups. There were fifty-five developing countries that rescheduled external debt. Fourteen of these countries had prolonged high inflation (annual inflation above 40 percent) and then later 
stabilized. Nineteen of the debt crises countries never had annual inflation pass 20 percent. ${ }^{1}$

Figure 1 shows median per capita income over 1980-93 in these two groups. Income in the low-inflation group kept falling until 1993 and only then flattened out. The inflation-stabilization group contracted until the mid-1980s, and since then recovered steadily. There is certainly nothing to indicate mechanical recovery after debt crisis in the no-inflation group; the recovery of the inflation-and-stabilization group is special.

As shown in the appendix, 9 of the 14 inflation-and-stabilization countries are in Latin America. The Franc Zone in West Africa forms 11 out of the 19 no-inflation countries. These countries for forty years had a fixed parity with the French Franc, and thus had low inflation. But they suffered a substantial real appreciation in recent years before undergoing a devaluation in January 1994.

Admittedly, inflation-and-stabilization versus no-inflation is mostly a story of Latin America versus Africa - - but not entirely. There are three African examples of stabilize-and-recover -- Guinea-Bissau, Uganda and to a lesser extent, Sierra Leone. Another successful African stabilizer cum reformer has been Ghana. ${ }^{2}$ Nor were the no-inflation group's travails limited to the CFA zone, as the eight non-CFA countries in the no-inflation group also had median negative growth over this period.

The troubles of the CFA zone are partly a reflection of chronically low African growth. But remember that CFA countries like Cameroon, Cote d'Ivoire, Gabon, and Togo were called success stories at different points in the 1960 s and 1970s -- Cote d'Ivoire had higher 
growth than Korea in the 1960s. The debt crisis of the early 1980s was a discrete output collapse for CFA and other low-inflation countries, and there was no mechanical recovery afterwards.

II. Did high inflation crises make countries act?

The idea that severe crises beget reforms has become common in the political economy case study literature. One survey went so far as to label reform-after-crises as "the new conventional wisdom" (Tommasi and Velasco 1994). Albert Hirschman (1988) suggested for Latin America that "in some developing economies inflation has acted as an equivalent of war" in eliciting change. Alesina and Drazen (1991) model delayed stabilization as a 'war of attrition' in which each group tries to shift the burden to another, until one of the groups eventually concedes and bears most of the costs. Drazen and Grilli 1993 suggested that high inflation could be a beneficial crisis under such circumstances. The costs of high inflation from monetization of the government deficit prompt a faster agreement among interest groups than would have occurred in the absence of inflation

In light of this literature, we ask three questions. Were countries that had high inflation and then inflation reduction taking policy actions to achieve this result? Did they do other nonstabilization reforms? Was there an inflation trigger above which countries stabilized?

Figure 1 shows that public sector deficits were worse early in the1980s in the inflation-and-stabilization group -- which had something to do with their inflation crises -- but then became better than in the no-inflation group. Current account deficits in the no-inflation group were higher than in the inflation-and-stabilization group throughout 
1980-93. In short, the inflation stabilizers adjusted, the no-inflation group did not.

Broader reforms were the children of high inflation crises. Mexico's recent troubles, prominent on Prime Time, should not erase the accomplishments of the Latin American reform movement. The response to inflation crises in this group included not only stabilization, but also central bank independence, privatization, pension reform, and trade liberalization, Chile being the archetypal example. Rodrik (1994, p. 81) noted that "no significant case of trade reform in a developing country in the 1980s took place outside the context of a serious economic crisis." The gains from resolving macroeconomic crises help compensate the losers from trade reform.

We find a strong association between our stabilization-from-highinflation measure and the "opening" measure of Sachs and Warner (1995). They define being "closed" as one or more of: high nontariff barriers, high average tariff rates, a high black market premium, a socialist economic system, or a state monopoly on exports. Twelve of our fourteen inflation-and-stabilization countries are classified by Sachs and warner as "open" by 1994. The date of the Sachs-Warner "opening" is close to our stabilization dates. ${ }^{3}$ Eleven of the sixteen no-inflation countries classified by Sachs and warner were still "closed" in 1994. Ten of the twenty-two reschedulers in neither of the polar groups were open by 1994, a nicely intermediate result.

One prediction of the political economy models is that a "severe" crisis makes you act, while you continue to muddle along with "moderate" crises. Drazen-Grilli, for example, say that a large increase in inflation today is beneficial by making you lower inflation tomorrow. 
The Drazen-Grilli prediction says the inflation today-inflation tomorrow relationship, normally thought to be monotonically positive, will become downward sloping at some point.

Figure 2 shows that the Drazen-Grilli prediction is indeed confirmed at least at extreme values of inflation. Figure 2 graphs the current year inflation against inflation lagged 5 years. To summarize what would be an unwieldy mass of data, we use the following device: we order all of the pairs of data points $(\pi(-5), \pi)$ according to $\pi(-5)$. We then do rolling medians for 40 observations, moving down one observation at a time. Each point represents the medians of $(\pi(-5), \pi)$ for these overlapping groups of 40 observations. We lower the sample size to 20 at the right-hand tail to get more detail on what is going on at the scarce high inflation observations. The use of rolling medians ensures that our findings are not sensitive to an arbitrary choice of dividing lines between successive inflation ranges. The line in figure 2 shows that median inflation turns down somewhere in the range between 150 and 200 percent lagged inflation. The difference between the median at the righthand tail of the graph and the median at the peak is statistically significant. Significance checks on the differences in the intermediate points between the peak and the tail are inconclusive.

III. What was the role of aid in crisis and reform? The beneficial crisis idea implies that a drop in aid may actually increase welfare as it shortens the reform delay -- unless the aid is conferred only upon reform. We can speculate that the lack of adjustment in current account deficits and budget deficits in the noinflation group had to do with a continuing high flow of overseas 
development finance (ODF, net bilateral and multilateral official credits) to the no-inflation countries (figure 1 again). The inflation-and-stabilization crowd started off the 1980 s with a like amount of ODF, but ODF then diminished throughout the 1980s and $90 \mathrm{~s}$. Grants (a subset of ODF) increased sharply in the no-inflation group; grants were modest in the inflation-and-stabilization group. Aid in the median low-inflation economy did start falling from 1990 onwards (which reflects the CFA zone).

There is a suggestive aid fact about the inflation today inflation tomorrow graph in figure 2. ODF is a function of lagged inflation, again using rolling medians for overlapping groups of 40 observations ordered by lagged inflation. The aid givers seem to implicitly condition ODF upon at least very high inflation -- ODF turns down at about 150-200 percent inflation. (Again the confidence interval for the median at the right hand tail indicates that it falls significantly below the peak.) Perhaps one extra incentive for stabilization and reform is the cutoff of aid for high inflations. The question remains as to what incentives should accompany aid for the more common low inflations.

IV. Conclusions

Recent reforms look like they are the children of high inflations. But further paternity tests are in order. Inflation's children have historically included violent revolutions as well as virtuous reforms. Even if high inflations promote reform, the challenge is to make reform happen more cheaply. 
References

Alesina, Alberto, and Allan Drazen. "Why Are Stabilizations Delayed?" American Economic Review, December 1991, 81(5): 1170-88.

Bruno, Michael and William Easterly, "Inflation Crises and Long-Run Growth", NBER Working Paper \#5209, 1995.

Drazen, Allan and Vittorio Grilli, "The Benefit of Crises for Economic Reforms," American Economic Review, June 1993, 83(3), 598-607. Easterly, William, "When is stabilization expansionary?", forthcoming, Economic Policy, April 1996.

Hirschman, -Albert-o. The strategy of economic development. Third edition, Westview Encore Edition. Boulder, Colo. and London: Westview Press, 1988.

Dani Rodrik, "The Rush to Free Trade in the Developing World: Why So Late? Why Now? Will it Last?", in S. Haggard and S. Webb, eds., Voting for Reform: Democracy, Political Liberalization, and Economic Adjustment, Oxford University Press, 1994. Sachs, Jeffrey and Andrew Warner, "Economic Reform and the Process of Global Integration," Brookings Papers on Economic Activity 1995:1, pp. $1-118$

Tommasi, Mariano and Andres Velasco, "Where are we in the political economy of reform?", Mimeo, May 1995. 


\section{Endnotes}

World Bank, Hebrew University, and NBER, and World Bank respectively.

Thanks for comments to our discussant Dani Rodrik, and to Mahsood Ahmed, Stijn Claessens, David Dollar, Carol Graham, Larry Hinkle, Christine Jones, Sarwar Lateef, Deborah Wetzel, and Holger Wolf.

${ }^{1}$ Debtors with high inflation and stabilization: Argentina, Bolivia, Chile, Costa Rica, Dominican Republic, Ecuador, Guinea-Bissau, Jamaica, Mexico, Nicaragua, Peru, Poland, Sierra Leone, Uganda. Debtors with inflation below 20 percent: Cameroon, Central African Republic, Chad, Congo, Cote d’Ivoire, Equatorial Guinea, Ethiopia, Gabon, Jordan, Liberia, Mali, Mauritania, Morocco, Niger, Panama, Senegal, South Africa, Togo, and Trinidad and Tobago. The other 22 debt rescheduling countries included 14 countries with moderate inflation (20-40) and 8 countries that still had high inflation above 40 percent annual. 2 Ghana is not in our sample because it could not borrow from the multinational banks in the 1970 s and thus did not go through external debt rescheduling. Sadly, Ghanaian inflation has been going up again recently.

${ }^{3}$ Stabilization and the Sachs and Warner "opening" are not fully independent. For example, the black market premium they used as a measure of openness may also reflect high inflation.

${ }^{4}$ Equatorial Guinea, Liberia, and Panama were not classified by Sachs and Warner. 
Figure 1: Comparing debtors with high inflation and stabilization to debtors with no inflation

Per capita income in debt-rescheduling countries with and without inflation

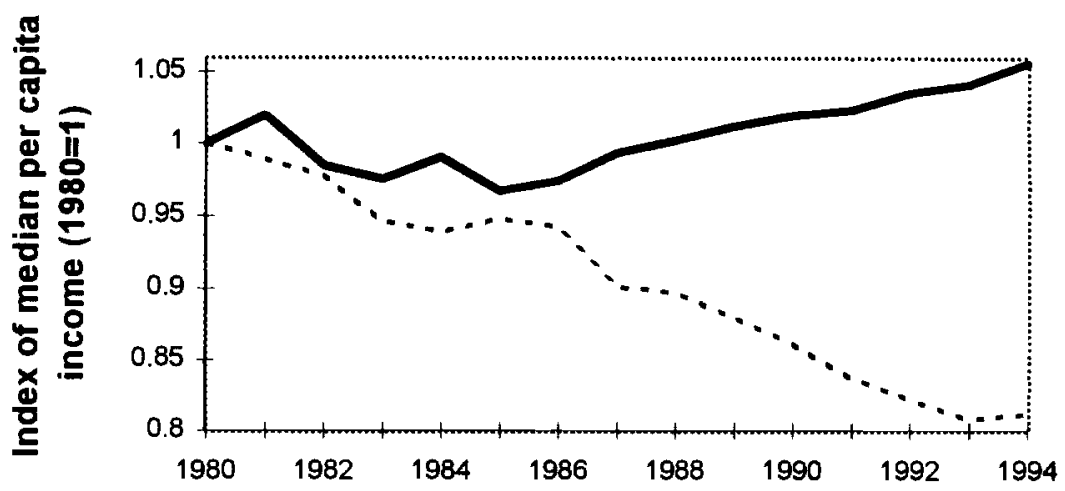

Public sector deficits in debtrescheduling countries with and without inflation

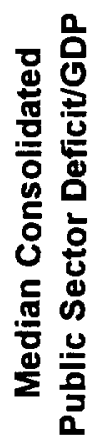

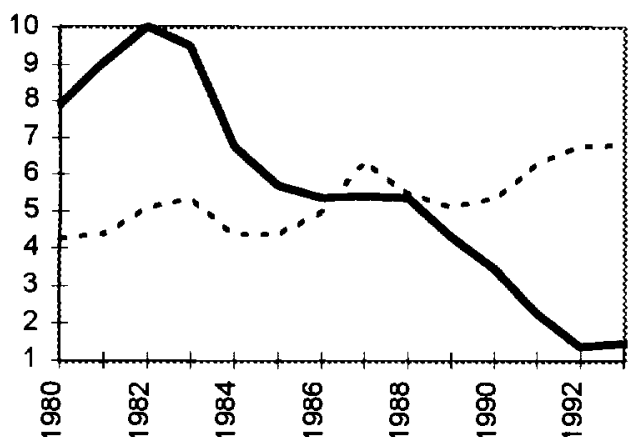

Overseas Development Finance in debtrescheduling countries with and without

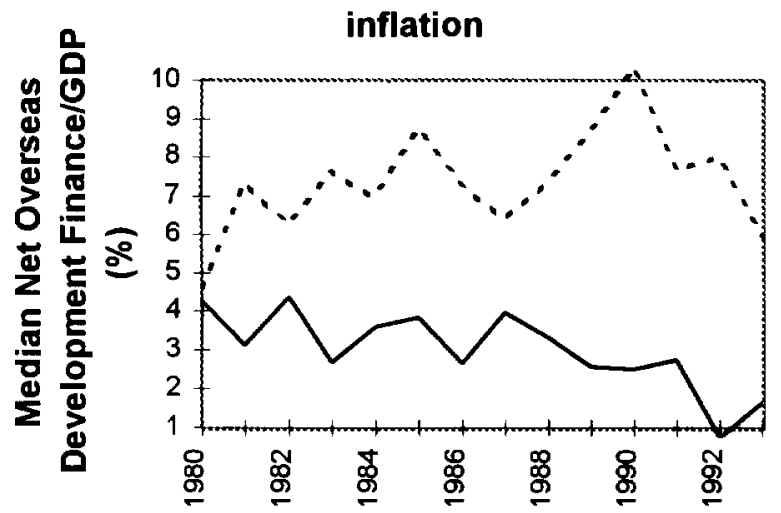

Current Account Deficits in debtrescheduling countries with and without inflation

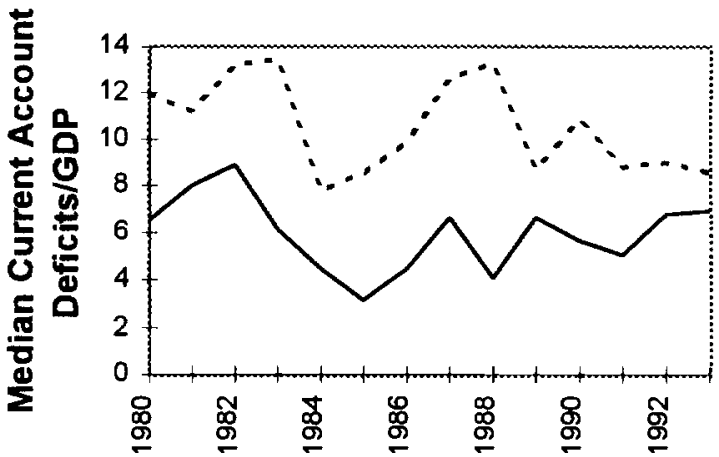

Grant/GDP ratios in debt-rescheduling countries with and without inflation

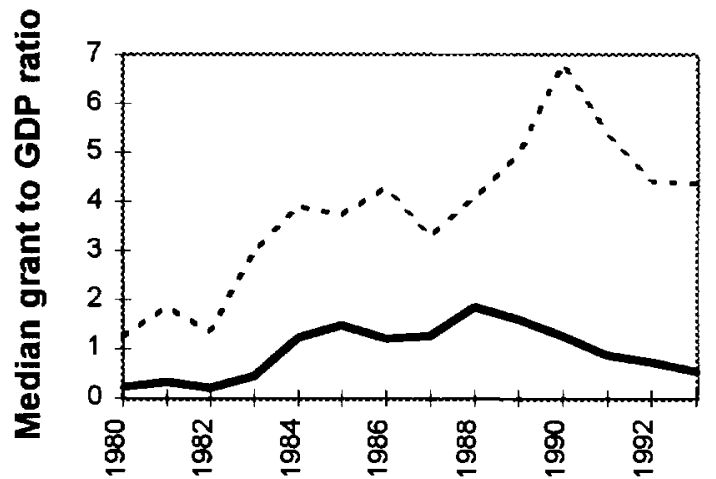

Samples: 13-14 for high inflation and stabilization and 16-19 for no inflation ...... Debtors with no inflation Debtors with high inflation and stabilization 
FIGURE 2:

\section{MEDIAN INFLATION VERSUS INFLATION LAGGED 5 YEARS}

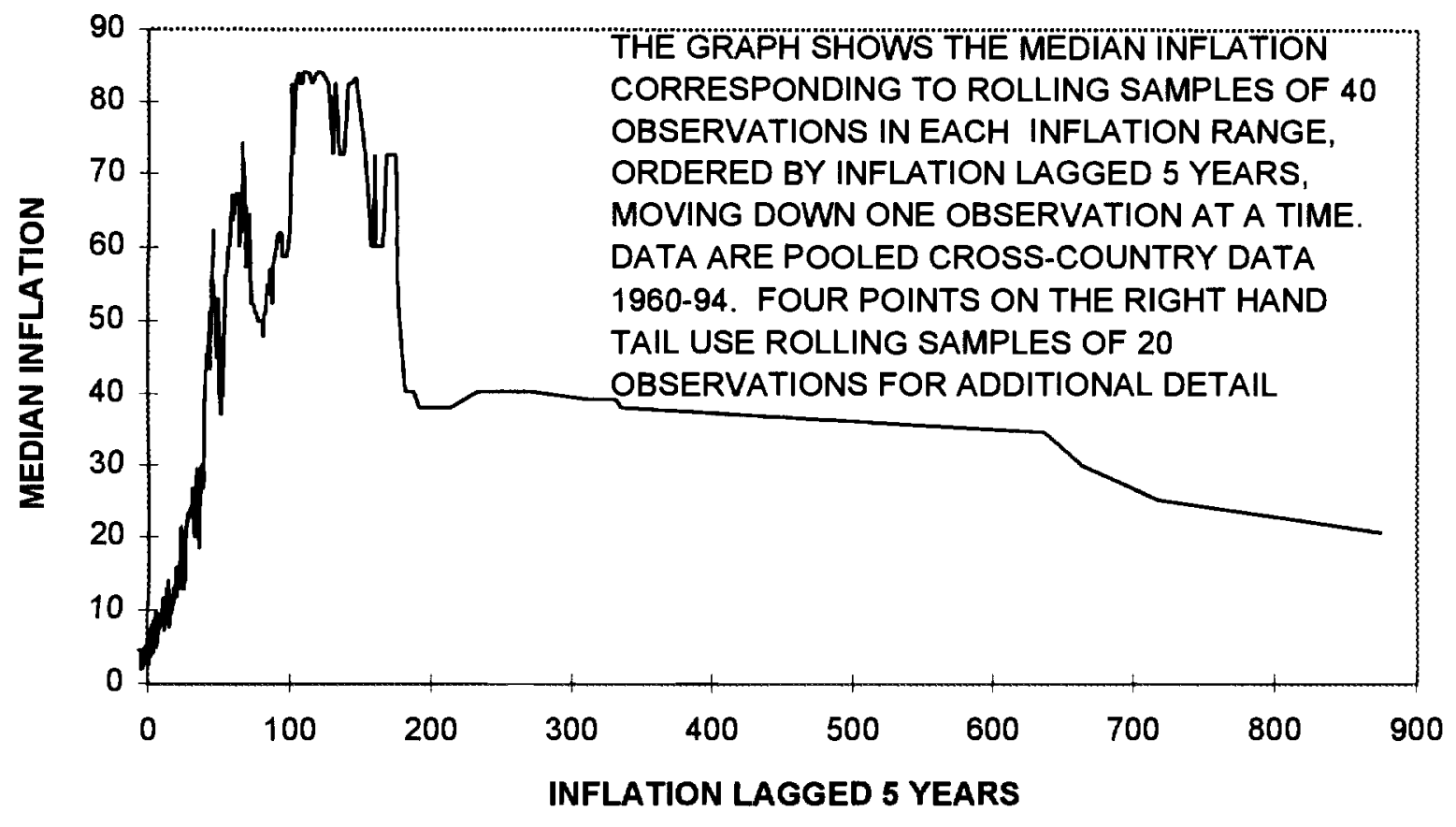

LAGGED INFLATION AND OVERSEAS DEVELOPMENT FINANCE TO GDP RATIOS

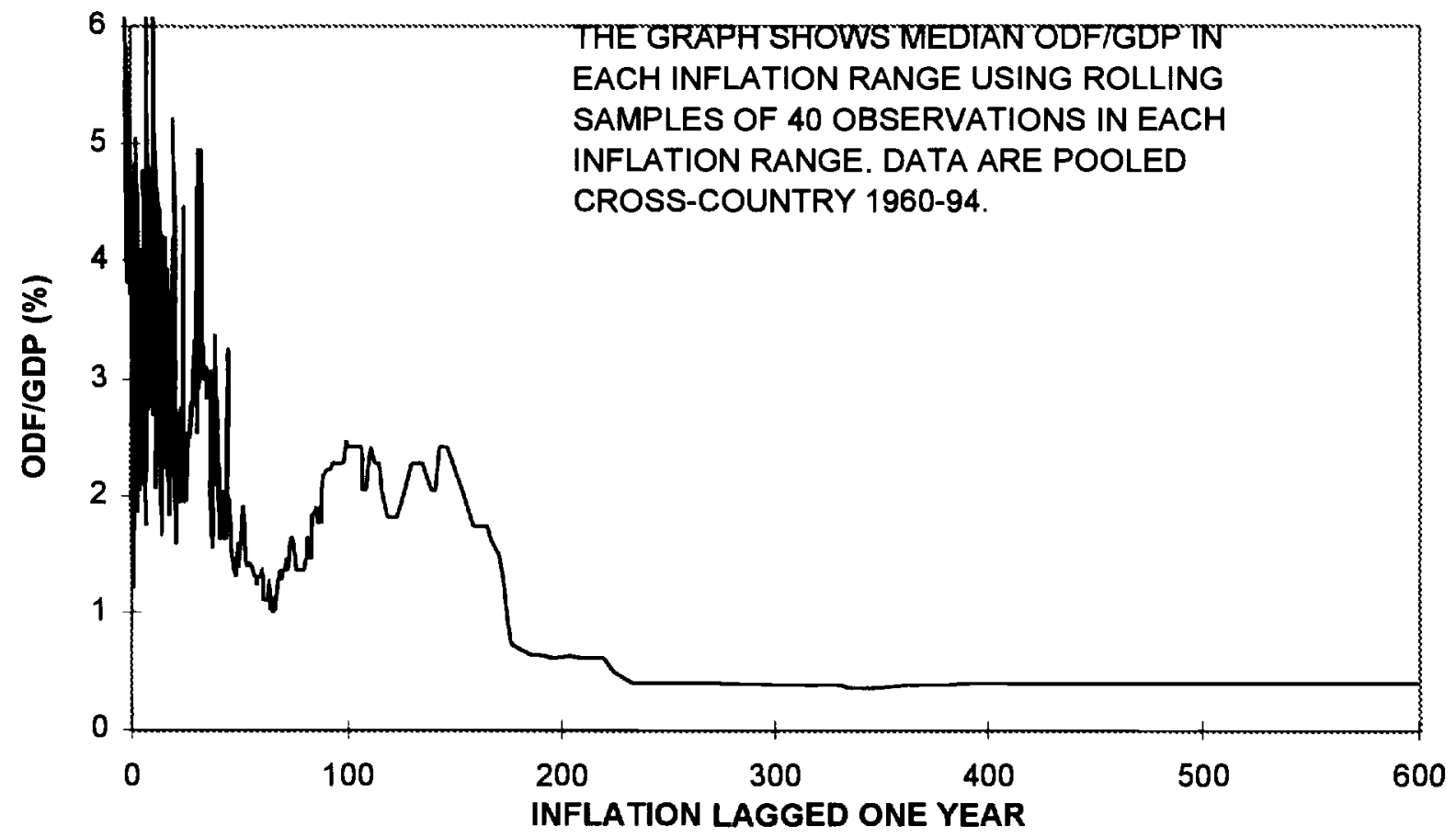

